\title{
Roger Brownsword (2020) Law 3.0: Rules, Regulation and Technology. Abingdon: Routledge
}

\author{
Cameron Downey \\ Queensland University of Technology, Australia
}

\section{ISBN: 9780367516406}

It is unequivocally recognised that technological advancements and technological changes will raise questions of legality. This recognition stems from the concern that legal intervention is required not only for the public good but also to manage how technology is utilised to regulate human life. For several decades, Professor Roger Brownsword of King's College London has been at the leading edge of thinking about law and technology. ${ }^{1}$ His 2020 book, Law 3.0: Rules, Regulation and Technology, represents a reflective and synthesised account of how technology may shape our legal system.

In 27 short chapters, Brownsword argues that there is a need to reimagine the law - not as an exclusive and defined set of rules (i.e., 'the law'), but as a broader regulatory environment. ${ }^{2}$ This environment would feature both familiar legal rules and nonnormative forms of regulating, such as designing a building in a particular way to reduce crime. ${ }^{3}$ The need for such a change in approach is premised on the disruption posed to existing notions of the legal system by the emergence of various technologies such as blockchain or cryptoassets. ${ }^{4}$

Brownsword frames this discussion by outlining three separate but coexisting 'mindsets'. These are:

Law 1.0: the traditional approach to the law, which involves the application of legal principles to specific fact situations. ${ }^{5}$ Synonymous with thinking like a lawyer, this is the default mindset of solicitors when advising a client or judges when justifying their decision. ${ }^{6}$

\footnotetext{
${ }^{1}$ Brownsword's contribution to 'technology law' is substantial, including: Brownsword, "Stem Cells, Supermen and the Report of the Select Committee"; Brownsword, Rights, Regulation and the Technological Revolution; Brownsword, "So What Does the World Need Now? Reflections on Regulating Technologies"; Brownsword, "In the Year 2061: From Law to Technical Management"; Brownsword, "Law, Innovation and Technology: Before We Fast Forward - A Forum for Debate"; Brownsword, Law, Technology and Society: ReImagining the Regulatory Environment; Brownsword, "Law, Regulation, and Technology: The Field. Frame and Focal Questions."

${ }^{2}$ Brownsword, Law 3.0, 5, 199.

${ }^{3}$ Brownsword, Law 3.0, 2.

${ }^{4}$ Brownsword, Law 3.0, 3.

${ }^{5}$ Brownsword, Law 3.0, 13, 117

${ }^{6}$ Brownsword, Law 3.0, 5, 32.
} 
Law 2.0: results from the arrival of new technologies. The classic application of rules in a Law 1.0 sense are disrupted, and jurisdictions begin asking whether existing rules are fit for purpose. ${ }^{7}$ The onus of articulating new rules and frameworks to regulate innovative technology shifts from the courts to the legislative and executive branches. ${ }^{8}$ This approach can be seen best in the enacting of a regulatory system to govern a specific technology.

Law 3.0: evolves from the disruption of the Law 2.0 mindset. As technologies increasingly present themselves as possible regulatory tools, jurisdictions move from the previous mindsets to question whether technologies could be employed to limit, mitigate or entirely prevent certain behaviours. ${ }^{9}$

While Law 3.0 is the book's inherent and titular focus, the other mindsets are discussed routinely to guide the reader from the familiar to the new. For example, the chapters in Part One compare a new mindset with its predecessor(s) to highlight how technology has led to or affected its development. Using all mindsets to present a layered analysis of real or fictitious scenarios is one of the book's key strengths. Opening with a discussion of Gatwick Airport's drone-related shutdown, Brownsword describes how the differing mindsets would combat drone use around airports in practice. ${ }^{10}$ His similar examination of the liability of robot-babysitters was also thought provoking. ${ }^{11}$

Overall, I agree with Brownsword's assessment. New and innovative technologies present themselves every day, and the common law — or even existing tools of the regulatory state on their own — cannot be relied upon for their effective management. Further, it is imperative that governments, law reform commissions, lawyers and law students alike continually consider how our technologically infused society can be improved. For too long, the legal profession has been averse to technological developments and defaulted to a Law 1.0 mindset. ${ }^{12}$ If a technology can be utilised (alongside black letter law) to discourage, limit or eliminate harmful, antisocial or criminal behaviour, it should be embraced. For example, mobile phone manufacturers have already begun incorporating features to dissuade drivers from using their mobile phones—such as Apple's 'Do Not Disturb While Driving', which blocks certain functions that may distract drivers. ${ }^{13}$

My only criticism of Brownsword is that this is not necessarily a new idea. Although he outlines instances where technology has been or could have been used as a regulatory tool (e.g., immobilising a vehicle if the driver is not wearing a seatbelt), ${ }^{14}$ Brownsword could have better emphasised his point that Law 3.0 is, to some extent, 'an old story'. ${ }^{15}$. Rather than 'reframing' or 'reinventing' how the law is perceived, the argument could be for a Law 3.0 mindset to become the more dominant or central attitude to regulation. I accept that this criticism may be semantic. However, one twentieth-century example of Law 3.0 is the construction of concrete barriers between road lanes - such barriers prevent the possibility of head-on collisions. While creative and unlikely scenarios can be imagined in which the barriers fail, it is generally accepted that barriers are effective physical mechanisms that contribute to safer roads by design. ${ }^{16}$ Reiterating that using technology as a regulatory tool is not a radical departure from current or previous thinking would, therefore, make the argument much easier for technophobes to swallow.

To conclude, Law 3.0: Rules, Regulation, and Technology is an introduction to how technology could change processes of governing in common law legal systems. Written to be 'read quickly, understood and retained', ${ }^{17}$ I would not limit my recommendation of this book to current or hopeful law students, but rather to the majority of the legal profession. It could assist not only the profession to move on from the traditional approaches to the law but also to dispel the law's residual technophobia regarding using technology to manage society.

\footnotetext{
${ }^{7}$ Brownsword, Law 3.0, 3, 21.

${ }^{8}$ Brownsword, Law 3.0, 3.

${ }^{9}$ Brownsword, Law 3.0, 1-4, 52-3.

${ }^{10}$ Brownsword, Law 3.0, 1-2.

${ }^{11}$ Brownsword, Law 3.0, 37-40.

${ }^{12}$ Brownsword, Law 3.0, 115.

${ }^{13}$ Oviedo-Trespalacios, “Can Our Phones Keep Us Safe?"657-68.

${ }^{14}$ Brownsword, Law 3.0, 56.

${ }^{15}$ Brownsword, Law 3.0, 119.

${ }^{16}$ World Health Organization, Global Status Report on Road Safety, 52.

${ }^{17}$ Brownsword, Law 3.0, 6.
} 


\section{Bibliography}

Brownsword, Roger. Law 3.0: Rules, Regulation, and Technology. Abingdon: Routledge, 2020.

Law, Technology and Society: Re-Imagining the Regulatory Environment. Abingdon: Routledge, 2019.

Rights, Regulation and the Technological Revolution. Oxford: Oxford University Press, 2008.

"So What Does the World Need Now? Reflections on Regulating Technologies." In Regulating Technologies: Legal

Futures, Regulatory Frames and Technological Fixes, edited by Roger Brownsword and Karen Yeung, 23-48. Oxford: Hart Publishing, 2008.

"Stem Cells, Supermen and the Report of the Select Committee." Modern Law Review 65, no 4 (2002): 569-87.

Brownsword, Roger "“In the Year 2061: From Law to Technical Management." Law, Innovation and Technology 7, no 1 (2015): 1-51. https://doi.org/10.1080/17579961.2015.1052642

Brownsword, Roger and Hans Somsen. "Law, Innovation and Technology: Before We Fast Forward - a Forum for Debate." Law, Innovation and Technology 1, no 1 (2009): 1-73.

https://doiorg.ezp01.library.qut.edu.au/10.1080/17579961.2009.11428364

Brownsword, Roger, Eloise Scotford and Karen Yeung. "Law, Regulation, and Technology: The Field. Frame and Focal Questions." In The Oxford Handbook of Law, Regulation Technology, 3-38. Oxford: Oxford University Press, 2017.

Oviedo-Trespalacios, Oscar, Mark King, Atiyeh Vaezipour and Verity Truelove. "Can Our Phones Keep Us Safe? A Content Analysis of Smartphone Applications to Prevent Mobile Phone Distracted Driving." Transportation Research Part F: Traffic Psychology and Behaviour 60, (January 2019): 657-668. https://doi.org/10.1016/j.trf.2018.11.017

World Health Organization. Global Status Report on Road Safety 2015. Geneva: World Health Organization, 2015. 